TECHNICAL TRANSACTIONS 8/2018

CIVIL ENGINEERING

DOI: $10.4467 / 2353737$ XCT.18.119.8894 SUBMISSION OF THE FINAL VERSION: 13/07/2018

\author{
Matthias Richter \\ Jan Paszkowski \\ jan.paszkowski@fh-zwickau.de \\ Fakultät Wirtschaftswissenschaften, Westsächsische Hochschule Zwickau
}

\title{
MODELLING DRIVER BEHAVIOUR IN TRAFFIC-CALMED AREAS
}

MODELOWANIE ZACHOWAŃ KIEROWCÓW

W OBSZARACH O RUCHU USPOKOJONYM

\begin{abstract}
The aim of this paper is to investigate driver behaviour in order to develop a method for improving microand macrosimulation traffic models with a particular focus on traffic calming solutions. Therefore, speed profiles were calculated, a PTV Vissim model was created, and an attempt to estimate volume-delay functions was made. Driver behaviour was modelled on the basis of video recordings of traffic in trafficcalmed links. Speed profiles were divided into parts where the speed is influenced with the traffic calming and not, and speed distributions were calculated in order to be used in Vissim. Vissim microsimulation was tested on various traffic volumes, with various traffic compositions, in order to identify the relationship between traffic flow and travel time.
\end{abstract}

Keywords: traffic calming, modelling, volume-delay function

\section{Streszczenie}

Celem niniejszego artykułu jest zbadanie zachowań kierowców na ulicach o ruchu uspokojonym, w celu stworzenia metody modelowania mikro- i makrosymulacyjnego ulic tego typu. Za pomocą nagrań wideo ruchu odtworzono trajektorie pojazdów w celu ustalenia wyglądu funkcji oporu odcinka. Prędkości zostały podzielone na te występujące w miejscach, gdzie ruch jest spowolniony z powodu urządzeń uspokojenia ruchu, oraz te, w których ruch odbywa się bez zakłóceń, w celu stworzenia modelu w programie PTVVissim. Model ten został przetestowany dla różnych natężeń ruchu, tak aby odkryć relację między natężeniem ruchu a zwiększeniem czasu przejazdu.

Słowa kluczowe: uspokojenie ruchu, modelowanie, funkcja oporu odcinka 


\section{Introduction}

Cities nowadays cope with increasing amount of cars, which, together with high urban density, can lead to a decrease in the attractiveness of the affected area. Over the years, urban planners and scientists have discovered that costly expansion of the road infrastructure does not give the desired results. One of the first discoveries was Braess's paradox (1968), which identified the mathematical chance of time loss caused by enlarging the road network [1]. Induced and latent demand [2] were discovered in 1969. Finally, the Downs-Thomson paradox [3] of risks of congestion in the case of unsustainable transport development and the Lewis-Mogridge position [4] proved that the bigger the car network, the greater the level of traffic and the more congestion will occur. Therefore, cities promote public transport, which is more flexible with a big demand than car transport. In order to encourage people to reduce car usage, the most radical idea is to completely close the most vulnerable zones to car traffic. However, to meet the needs of the inhabitants of these zones and those whose places of work lie within these areas, car traffic must be maintained. Therefore, a solution which redirects transit traffic from the vulnerable areas to the transit roads, is needed - one such solution is traffic calming. Traffic calming devices are often applied in zones with a large amount of pedestrians, for example, in residential areas or city centres.

\subsection{Traffic calming}

Traffic calming is a set of measures, the purposes of which are to reduce the negative effects of motor vehicle use, alter driver behaviour and improve conditions for non-motorised street users. [5] That includes reduction of traffic volume, thus noise and air pollution, improvement of road safety level, and the quality of life. Another aim of traffic calming is to change travel behaviour, such as by reducing the share or car travel in the modal split in favour of public transport, and changes to the traffic assignment, especially with regard to reducing transit traffic in the problem area. The traffic calming measures can be divided in two groups: area and point traffic calming. Area traffic calming is, for $30 \mathrm{~km} / \mathrm{h}$ speed limit zones, reduced access zone, residents only zone, and shared Point traffic calming refers to measures that are placed at specific points on the road, for example: speed humps, speed cushions, elevated street at pedestrian crossing areas, narrowing of the street, chicanes.

\section{Area}

The area examined in this paper is Stachiewicza Street in Kraków. It is located in the Prądnik Biały district, in the Azory residential area. This street runs from north to south in the central area of this district. It is one of the main routes connecting the north-western outskirts and suburbs of Kraków with the western part of the city centre, as well as the main north-south transit avenue - Aleja Trzech Wieszczów. Public transport buses operate on those street, creating a connection between stated above areas and the city centre. On the 
southern end of Stachiewicza street is the railway underpass and the Kraków Łobzów station. There are two other streets parallel to Stachiewicza street, one on each side, but with level railway crossings instead of an underpass. During the measurements, one of the level railway crossings was closed due to reconstruction of the railway.

A primary school is located on the analysed Stachiewicza street. One of the main routes between the Azory area and the school crosses Stachiewicza street. On both sides of the crossing, in both directions, there are traffic calming devices installed - speed cushions to slow down car traffic without lowering the comfort level for bus passengers.

\section{Measurement methods}

To reproduce driver behaviour to a high level of precision, it was necessary to have precise vehicle motion recorded including data relating to speed, acceleration and braking. Moreover, for further investigation of the problem, it was important to note interactions between vehicles; these interactions between vehicles include the distances between successive vehicles, braking forces when noticing the approach to the car in front, and the speed and distance fluctuations when following. These parameters can be adopted in the Wiedemann model, used in PTV Vissim software.

The measurement types can be divided into two categories: inside and outside the vehicle. Measurements inside the vehicle, known also as floating car, stands, that there is a measurement car, equipped with movement tracking device, such as car computer, recording distance travelled and speed of the car, or additional values, such as acceleration and braking pedal press. Another solution for floating car motion recording is the use of GPS devices, which record not only the speeds of the vehicle, but also its trajectory; this means that in every time stamp (for example one second), the position of the vehicle is recorded. When using this method, it should be noted that GPS has an accuracy of 2-5 meters [6], which can have a negative influence on the results. Measurements outside the vehicle, unlike the methods above, are able to record the behaviour of more than one vehicle. These methods include strategies such as pneumatic tubes for speed measurement. or radar control [7], can be connected to speed control, photographing or video recording facilities. Unfortunately, most of these methods are only working in one specific point of the measured road or area; therefore, it is needed to provide measurements in more points. However, gaps between measurement points still exist.

In order to ensure continuity in the recording of every vehicle in the traffic flow, video recording can be used. Previously, analysis of the video and identification of the vehicles trajectories were performed manually and this was a very time-consuming task. Nowadays, with the use of deep machine learning through creating classifiers, it is possible do detect vehicles automatically, trace them, and produce trajectories.

The area which can be recorded depends on the angle of the camera and the obstacles which covers the traffic, as well as the shape of the road, which can limit the size of the area that can be recorded. The optimal solution is to position the camera in such a manner that it 
is recording from above in order to minimize the amount of obstacles, as well as to simplify the trajectory calculations. This would mean installing the camera at a point high above the street or to record from the air. To provide coverage of a great area, when only low buildings are present, an unmanned quadcopter was used, hovering 80 meters above ground level, and recording the traffic along an approximate length of 110 meters of road. The quadcopter used is able to fly for around 25 minutes, which, taking into account a safe reserve of battery time, take off, positioning above the street and landing, leaves around 15-20 minutes of traffic recording at any one time. Recordings were made at a high definition of $1920^{*} 1080$ pixels resolution, and 40 frames per second.

The trajectories from the video were processed by the company DatafromSky [8]. The result of processing is delivered in two files - one of these is the file for the DatafromSky viewer software which is used to visualise the results, and the other is the csv file with all the data, containing timestamp, coordinates, object ID, and object type (car, heavy vehicle, bus, bicycle, pedestrian). The screenshot of the DatafromSky viewer software is presented in Fig. 1.

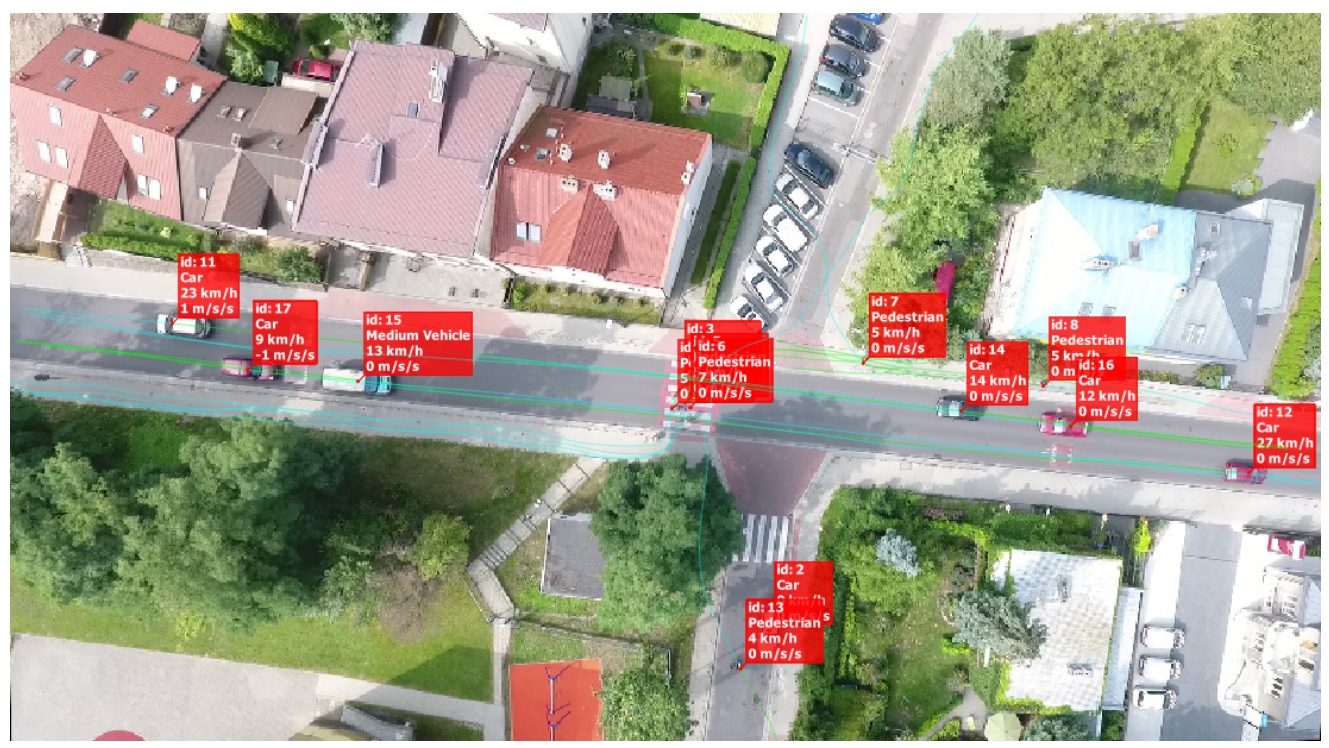

Fig. 1. DatafromSky viewer software screenshot with car detection and trajectory data displayed (source: own work)

\section{Measurement results}

The data acquired from recordings was processed. The street visible in Fig. 1 was divided into $10 \mathrm{~cm}$ sections and for each section instantaneous velocities were identified for every vehicle, divided to vehicle classes, such as cars (standard and van), busses and heavy vehicles. From these speeds, charts showing the speed profiles have been for different points along the analysed road, including the installed speed cushions. The following measurement results are based on approx. 20 minutes recording and contain trajectories of a total of 192 vehicles: 165 
cars, 18 vans, 3 heavy vehicles, and 6 buses. There were also 90 pedestrians detected, but for the purposes of the model, only vehicles have been taken into the consideration. Charts of speed profiles are presented below in Figs. 2 and 3.

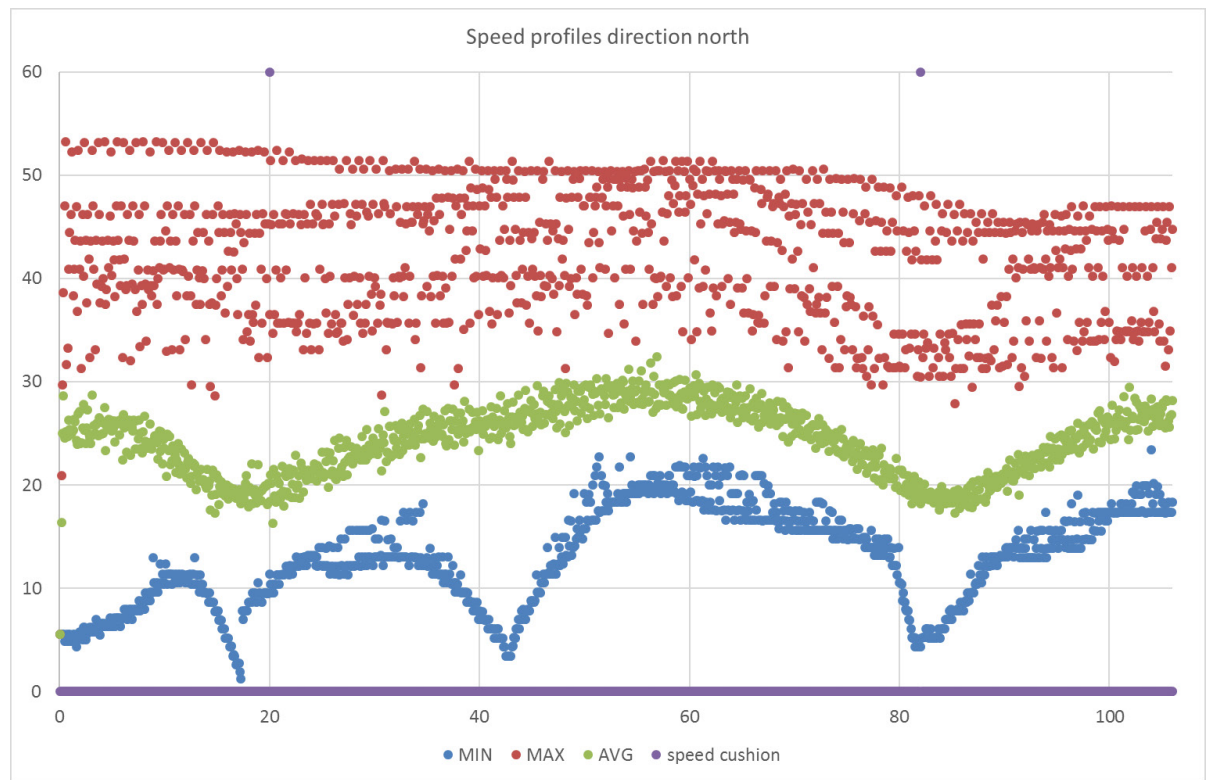

Fig. 2. Speed profile for Stachiewicza street, direction north consider changing to 'northbound' (source: own work)

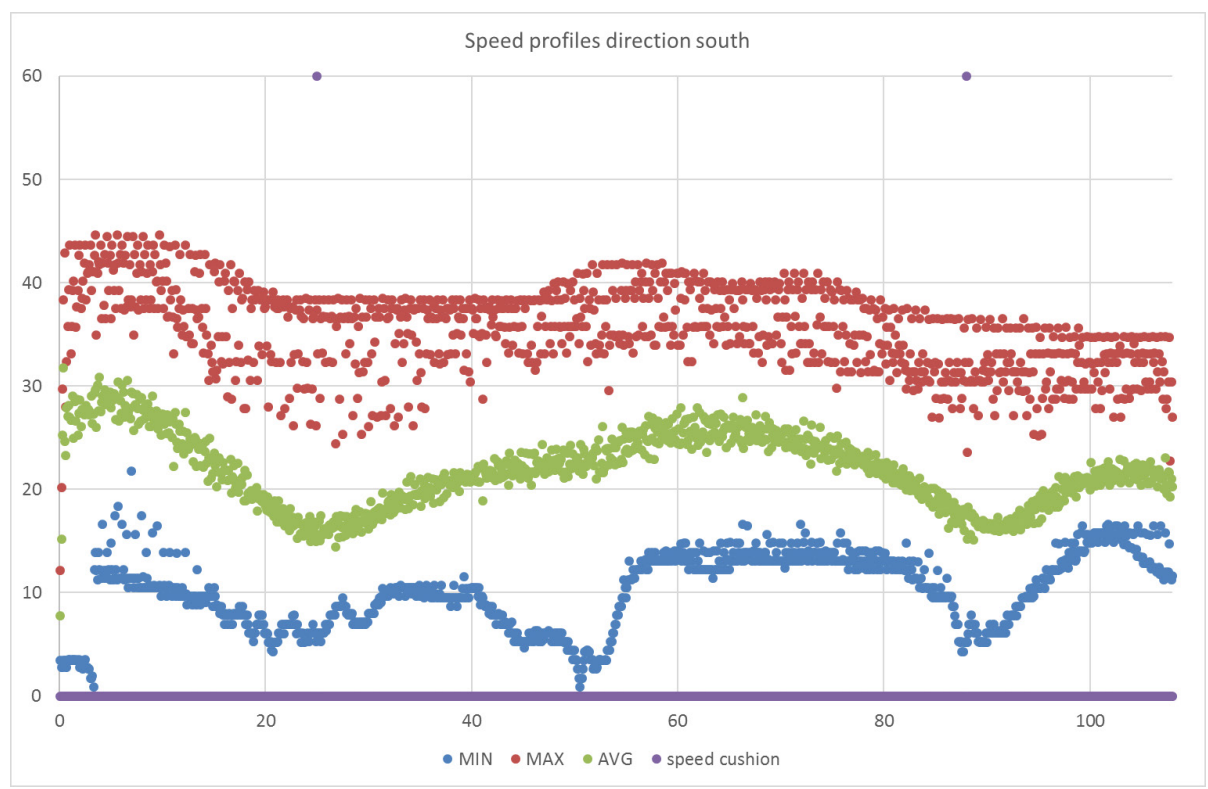

Fig. 3. Speed profile for Stachiewicza street, direction south consider changing to 'southbound' (source: own work) 
On the charts, the studied 107-metre length of Stachiewicza Street can be seen. Speed cushions, as indicated by the violet line, are located at 20 and 82 metres along this section northbound, whereas southbound - on $26^{\text {th }}$ and $88^{\text {th }}$ meter. The blue points indicate the minimum speed. The decrease of the minimal speed between the speed cushions (between 40 and 60 metres) depicts the car stopping on the pedestrian crossing. The green points show average speeds - slowing down in the area of speed cushions are clearly visible. Maximal speeds, marked with red points, show that not every vehicle is decelerating on speed cushions, especially, on the first device in the northbound? direction. possibly because some of the vehicles avoid speed cushions by driving between them.

\section{Microsimulation - PTV Vissim}

\subsection{Preparation}

A microsimulation model was created on the basis of the measurements. The model was prepared using the PTV Vissim software. Vissim's traffic flow model is a stochastic, timestep based, microscopic model that treats driver-vehicle units as the basic entities. The car following model is based on the Wiedemann model. Driving behaviour in this model is divided to four states: free driving, approaching, following, braking. Driving behaviour in detail is described with Wiedemann model parameters: Wiedemann 74, such as safety distances, lack of attention duration or lack of attention probability and Wiedemann 99: time distribution of the speed-dependent part of the desired safety distance, time of deceleration before reaching safe distance, influence of distance on speed oscillation, desired acceleration

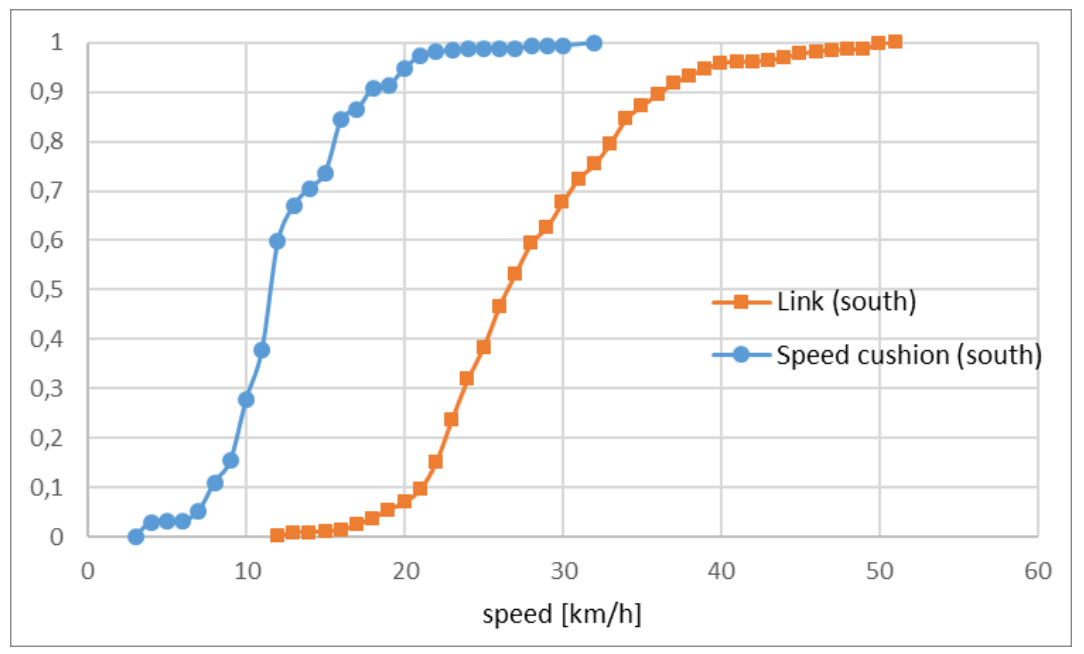

Fig. 4. Car speed distributions for the link, direction south (orange) 'southbound link'? (although, see above note re use of 'link') and its second speed cushion (blue) (source: own work) 
when starting from standstill. Initially in this paper, the basic parameters of the model, such as speeds and accelerations, were taken into consideration without modifying the Wiedemann parameters describing interactions between vehicles [9].

For the each vehicle type, speed distributions have been created according to measured cumulated frequencies, for two kinds: near or away the speed cushions On the slowing down and speeding up areas around the speed cushions, the accelerations and decelerations were identified. The model consists of two links, representing two directions of the road and four reduced speed areas, one for each speed cushions. Speed distributions parameters for both links and all four reduced speed zones were inputed. Two examples of speed distributions are presented in Fig. 4.

\subsection{Comparison and calibration}

After inputting all of the speed distributions to the Vissim model, the simulation was started for the same traffic flow as was observed during the measurement. The results of the simulation were exported and extracted as average speed profiles of all vehicles in order to compare them with the measurements. Calibration of the model required using only the speed distributions of unimpeded vehicles - otherwise, the simulated speeds were higher than measured. The shape of the speed profile was calibrated by estimating the acceleration and the braking characteristics of the vehicles. For the first direction (northbound), the correlation between the model and the measurement is 0.79 . The compared speed profiles are presented in Fig. 5.

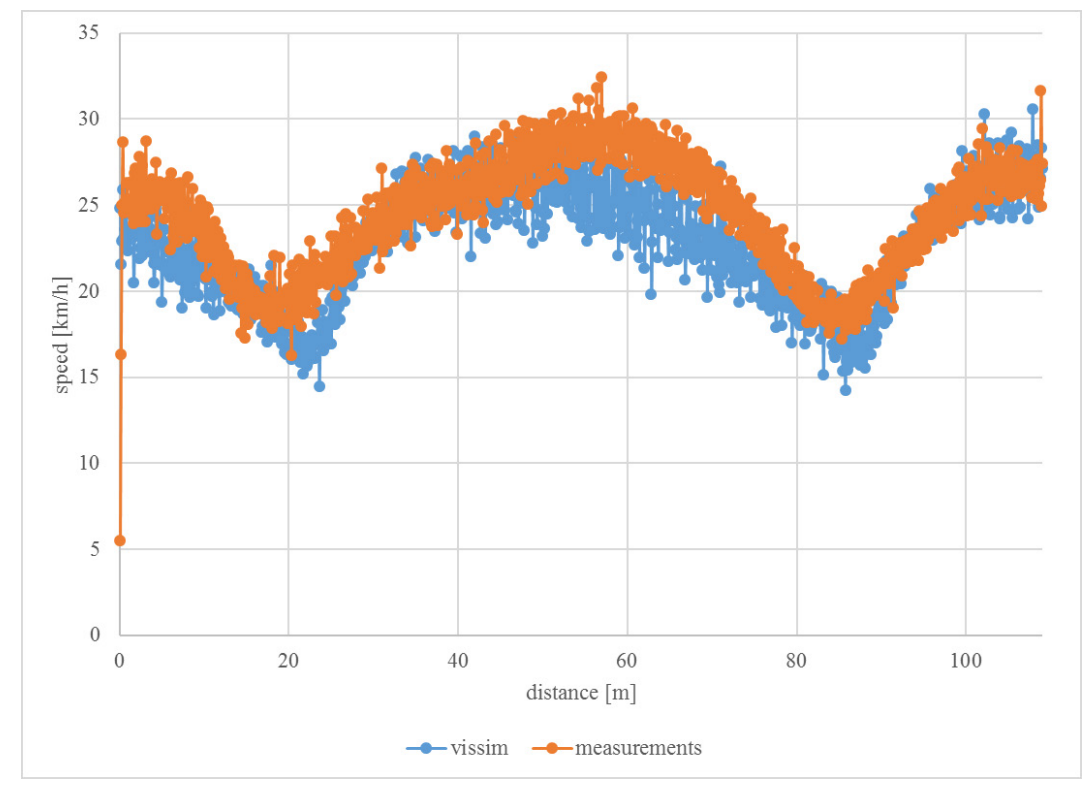

Fig. 5. Comparison of speed profiles on the measured street section, heading north 'northbound'? (source: own work) 
For the second direction (south 'southbound'?) along Stachiewicza street, the correlation between the measured and modelled speed profiles is 0.71 . Fig. 6 shows this comparison.

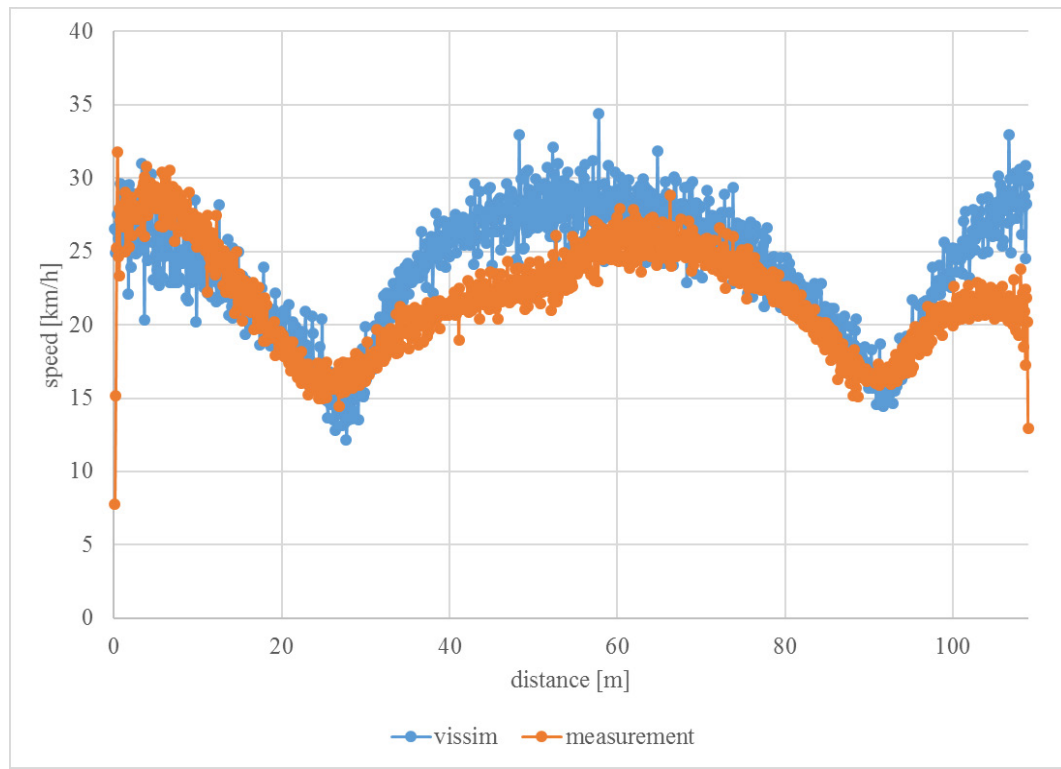

Fig. 6. Comparison of speed profiles on the measured street section, heading southbound (source: own work)

Comparing the measured and simulated speed profiles, a strong correlation between the speeds both in and out of the area of the traffic calming device can be observed. However, there is a difference in the shape of the speed profiles between the speed cushions. To minimise this difference, further activities should be undertaken, such as adaptation of the Wiedemann model parameters, acceleration and braking, or dividing the link into speed zones.

\section{Use of the volume-delay functions in the macrosimulation model}

Results of microscopic link model, done in PTVVissim lead to estimating suitable network link characteristics of PTV Visum. This kind of model consists of two main parts: demand and supply. Demand is represented by an origin-destination matrix between the traffic areas, with homogenous urban and transport functions. Supply is the transport network, set for various transport modes, both private and public. The aim of the model is to assign the trips from origin to destination to the road network Traffic assignment is calculated by setting a path with the lowest cost (for example, travel time) for every network user. In this project, demand remains unchanged, although link parameters regarding traffic were modified. Traffic on the link is described in terms of three basic variables: traffic flow $\mathrm{q}$ - amount of vehicles passing one point in a given period of traffic density - amount of vehicles on the link and their velocities. In the PTV Visum model, the relationship between the amount of traffic flow 
and the link travel time is described by volume-delay functions, which is one of the Visum link type parameters. Their shape can be chosen from default function formulas, and their parameters can be freely changed.

\section{Experiment and results}

Measuring, modelling and simulating driver behaviour under varying flow conditions and creating a microsimulation model will facilitate understanding of the relationship between traffic flow and travel time and allows formulating the volume-delay functions for traffic calmed roads. To reach this aim, Various traffic flows were tested and compared for trafficcalmed and not traffic-calmed links. In the simulation, the links were lengthened beyond the limits of the drone camera coverage, reaching the nearest intersections without right-ofway: Wybickiego and Radzikowskiego street on the southern end, and Makowskiego on the northern end. The length of the simulated link is 568 meters. In the simulation, the vehicle composition stays the same as during the measurements for both directions; for direction 1 (northbound) these are: cars, $82 \%$; HGVs, $16 \%$; buses, $2 \%$. For direction 2 (southbound), the proportions are: cars, $84 \%$; HGVs, $14 \%$; buses, $2 \%$.

\subsection{Capacity}

As mentioned above, the Vissim microsimulation model was tested for the whole range of traffic flows. The minimal traffic flow simulated was around 100 vehicles per hour. The capacity of the link was estimated in Vissim through increasing the traffic flow until the message about achieving maximum traffic flow was displayed. Maximum traffic flows were estimated in Vissim by increasing traffic flow until no more vehicles were able to pass the link in the simulated period of time. A comparison of maximal traffic flow, counted as vehicles per hour, for traffic-calmed and non-traffic-calmed (standard) streets is presented in Table 1.

Table 1. Comparison of maximal traffic flow for both directions with and without traffic calming

\begin{tabular}{|c|c|c|}
\hline Direction & 1 (north) & 2 (south) \\
\hline Traffic calmed [veh/hour] & 1068 & 1044 \\
\hline Standard [veh/hour] & 1308 & 1158 \\
\hline
\end{tabular}

\subsection{Speed}

The relation between amount of traffic flow and the traffic speed was calculated by analysing the results of the simulation. In both directions, the speed functions for with and without traffic calming are parallel to each other, with a difference of speed equal to $2.5 \mathrm{~km} / \mathrm{h}$ for direction 1 and $2 \mathrm{~km} / \mathrm{h}$ for direction 2 . The speed with traffic calming decreases from $41 \mathrm{~km} / \mathrm{h}$ to $24 \mathrm{~km} / \mathrm{h}$ for direction 1 , and from $35 \mathrm{~km} / \mathrm{h}$ to $18 \mathrm{~km} / \mathrm{h}$ for direction 2. Speed charts are presented in Fig. 7. 

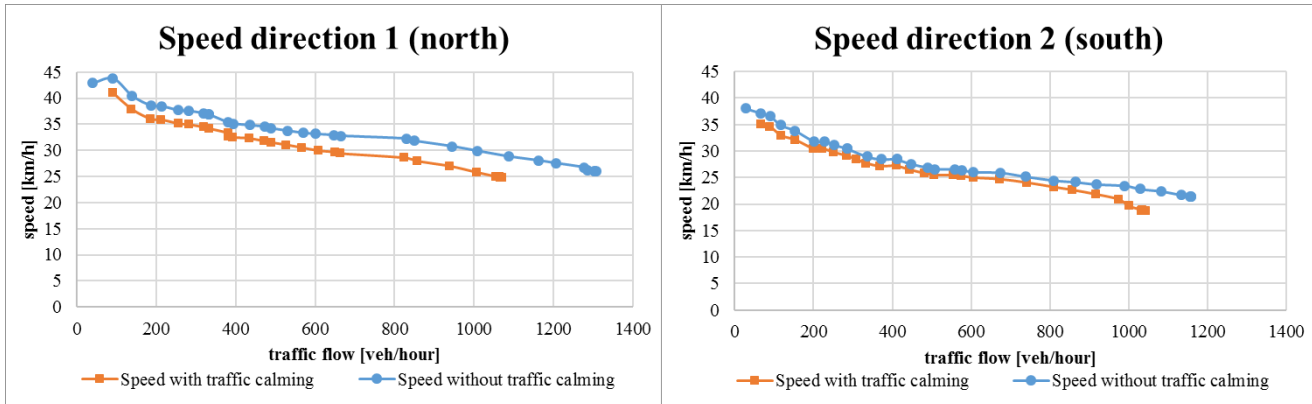

Fig. 7. Relationship between speed and traffic flow (source: own work)

\subsection{Travel time}

The next chart shows the growth of the travel time in the link. For direction 1 , the shortest travel time for the lightest traffic flow is 50 seconds, and increasing linearly to around 80 seconds for the heaviest traffic flow. For direction 2, the minimal travel time amounts around 60 seconds, and grows to around 100 seconds for the non-traffic-calmed street, and 110 seconds for the road with traffic calming. Both travel times increase similarly in lower traffic flows; however, with the traffic flow above around 900 vehicles per hour, the traffic-calmed street travel time starts to increase sharply.
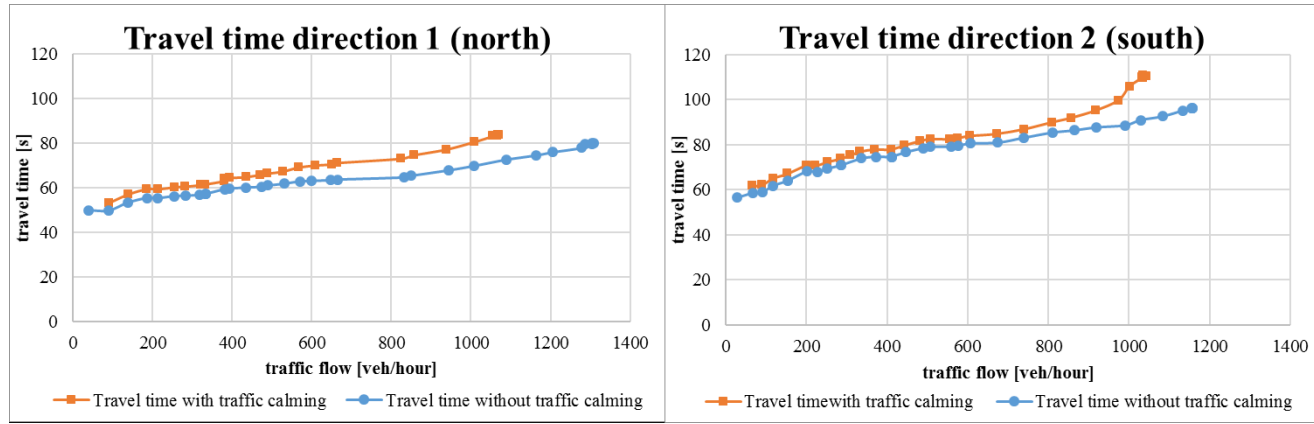

Fig. 8. Relationship between travel time and traffic flow (source: own work)

\subsection{Delay}

In PTV Vissim, delay is defined as the difference between the shortest, ideal travel time and the actual travel time for each vehicle. As expected, in the minimal traffic flows, delay amounts to zero. For direction 1, delay times are similar for both link types until the traffic flow is around $500 \mathrm{veh} /$ hour, then the delay for the traffic-calmed roads starts to increase more sharply. At the maximal traffic flow, the delay is 26 seconds for both link types. For the opposite direction, delay amounts are the same until the traffic flow is around 800 vehicles per hour, then the delay on the traffic calmed road increases sharply to reach a maximum delay of 45 seconds, whereas the non-traffic-calmed street reaches 32 seconds of delay. 

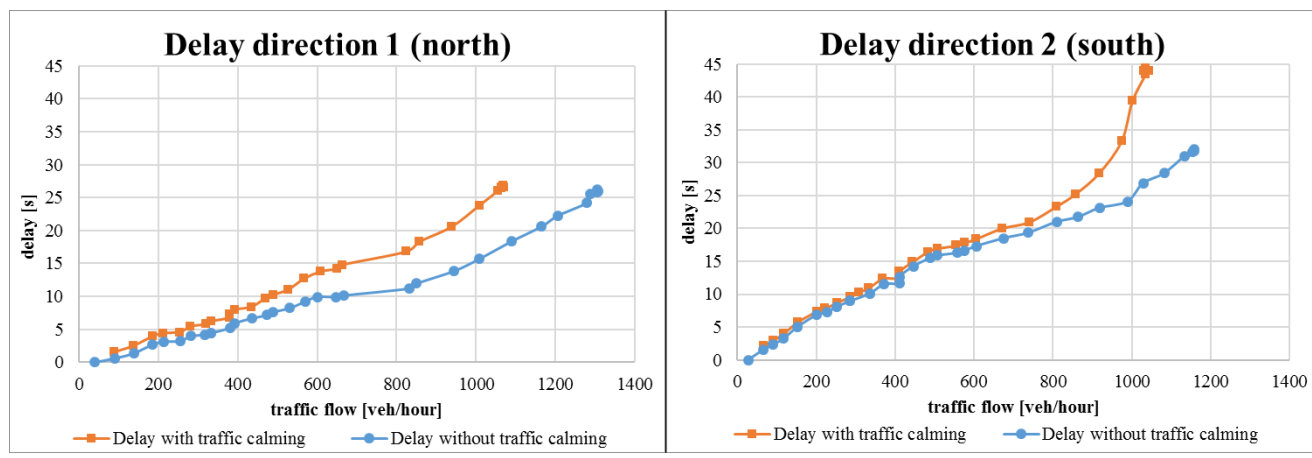

Fig. 9. Relationship between delay and traffic flow (source: own work)

\section{Visum volume-delay function}

Travel times were calculated in such a manner, to correspond with the form of volumedelay function available in PTV Vissim, thus showing the relationship between saturation grade (traffic flow divided by maximum traffic flow) and the travel time gain compared to $\mathrm{x}^{*} \mathrm{t}_{0}\left(\mathrm{t}_{0}\right.$ - free flow travel time). In the Kraków transport model, volume-delay function were estimated based on BPR2 volume-delay function shape, with five sets of parameters. The formula of the volume-delay function is:

$$
t_{\text {cur }}= \begin{cases}t_{0} \cdot\left(1+a \cdot \mathrm{sat}^{b}\right), & \text { sat } \leq \mathrm{sat}_{\text {crit }} \\ t_{0} \cdot\left(1+a \cdot \mathrm{sat}^{b^{\prime}}\right), & \text { sat }>\text { sat }_{\text {crit }}\end{cases}
$$

where:

$t_{0}$ - free flow travel time

$a, b, b^{\prime}$ - shape parameters

sat - saturation grade

In the Kraków transport model, the following parameters of volume-delay functions are given:

Table 2. Comparison of BPR function parameters

\begin{tabular}{|r|c|c|c|c|c|}
\hline \multicolumn{1}{|c|}{ Number of function } & $\mathbf{0 1}$ & $\mathbf{0 2}$ & $\mathbf{0 3}$ & $\mathbf{0 4}$ & $\mathbf{0 5}$ \\
\hline $\mathrm{a}=$ & 1.00 & 0.91 & 1.71 & 1.15 & 1.32 \\
\hline for sat $<1 \mathrm{~b} 1=$ & 2 & 6 & 4 & 3 & 3 \\
\hline for sat $>=1 \mathrm{~b} 2=$ & 2 & 6 & 6 & 6 & 6 \\
\hline
\end{tabular}

\subsection{Comparison with estimated BPR function parameters}

For the analyzed Stachiewicza street, in Kraków model, none of the functions were used - instead, constant function of travel time was implemented. According to the simulation results, the parameters of the BPR function were estimated. In order to obtain better function fitting, the BPR function was divided into two sections: 


$$
t_{\text {cur }}=\left\{\begin{array}{cc}
t_{0} \cdot\left(1+a \cdot \mathrm{sat}^{b}\right), & 0<\frac{\mathrm{sat}}{\mathrm{sat}_{\text {crit }}}<x \\
t_{0} \cdot\left(1+a \cdot \mathrm{sat}^{b^{\prime}}\right), & x<\frac{\mathrm{sat}}{\mathrm{sat}_{\text {crit }}}<1 \\
\ldots &
\end{array}\right.
$$

where: $x$ is the border value of saturation grade between two sections
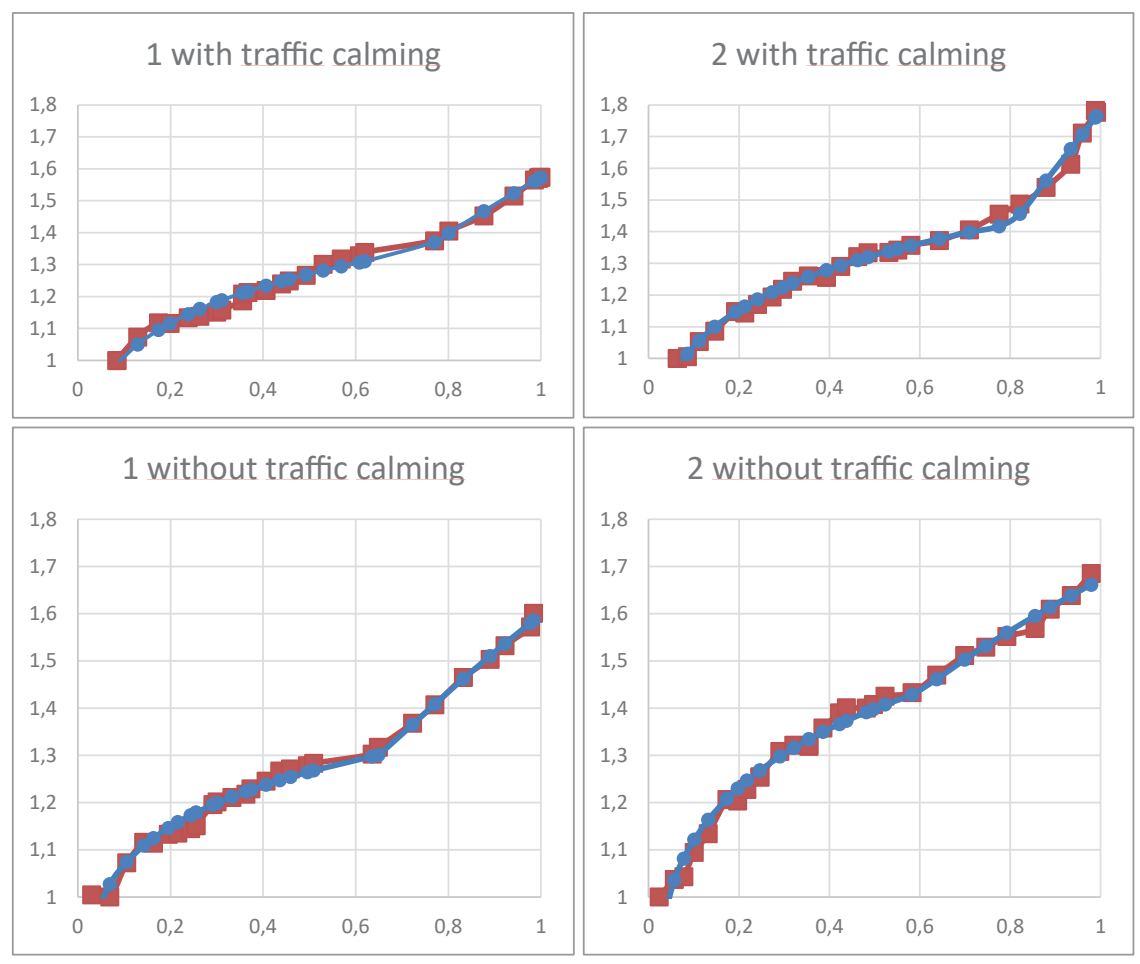

Fig. 10. Comparison of results and BPR function fitting (source: own work)

The parameters of the BPR function were estimated using squared difference minimization method. On the table below, the result of estimation is showed in Table 3.

Table 3. Estimated BPR function parameters

\begin{tabular}{|c|c|c|c|c|}
\hline $\begin{array}{c}\text { Number } \\
\text { of } \\
\text { function }\end{array}$ & $\begin{array}{c}\text { Direction } 1 \\
\text { with traffic calming }\end{array}$ & $\begin{array}{c}\text { Direction } 2 \\
\text { with traffic calming }\end{array}$ & $\begin{array}{c}\text { Direction } 1 \\
\text { without traffic calming }\end{array}$ & $\begin{array}{c}\text { Direction 2 } \\
\text { without traffic calming }\end{array}$ \\
\hline $\mathrm{a}=$ & sat $<0.7$ satcrit $\mathrm{a}=1.40$ & sat $<0.8$ satcrit $\mathrm{a}=1.47$ & sat $<0.7$ satcrit $\mathrm{a}=1.36$ & sat $<0.6$ satcrit $\mathrm{a}=1.54$ \\
\hline $\mathrm{a}=$ & sat $>0.7$ satcrit $\mathrm{a}=1.57$ & sat $>0.8$ satcrit $\mathrm{a}=1.78$ & sat $>0.7$ satcrit $\mathrm{a}=1.6$ & sat $>0.6$ satcrit $\mathrm{a}=1.67$ \\
\hline $\mathrm{b}=$ & sat $<0.7$ satcrit $\mathrm{b}=0.14$ & sat $<0.8$ satcrit $\mathrm{b}=0.15$ & sat $<0.7$ satcrit $\mathrm{b}=0.11$ & sat $<0.6$ satcrit $\mathrm{b}=0.14$ \\
\hline $\mathrm{b}=$ & sat $>0.7$ satcrit $\mathrm{b}=0.52$ & sat $>0.8$ satcrit $\mathrm{b}=1.02$ & sat $>0.7$ satcrit $\mathrm{b}=0.48$ & sat $>0.6$ satcrit $\mathrm{b}=0.30$ \\
\hline
\end{tabular}


The fitting of functions, compared to empirical results, were presented in ill. 10. Correlation factor for the functions is between 0.9 and 0.95 .

On the chart (Fig. 11) used shapes of BPR functions and measured volume - delay relations.

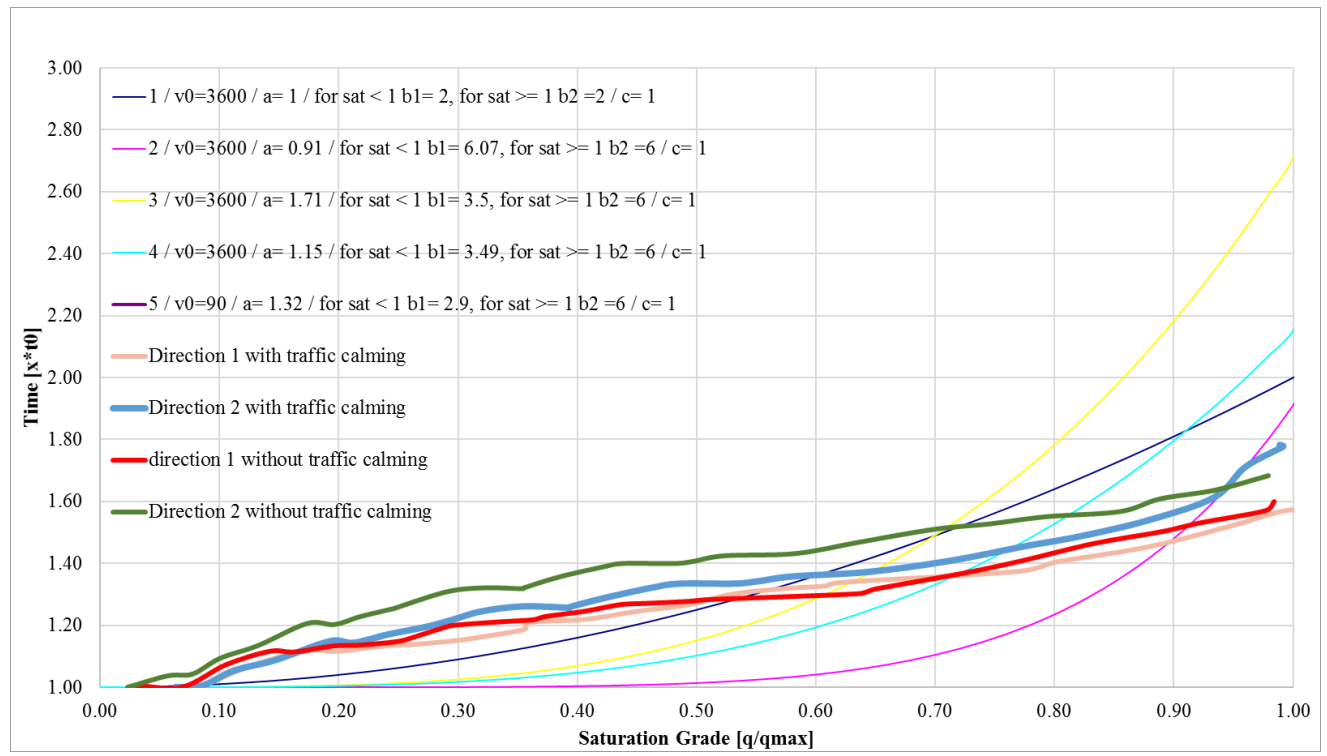

Fig. 11. Comparison of measured volume-delay functions and volume-delay functions used in the Kraków model, and on the analyzed street (source: own work)

\section{Summary and possible further research}

This paper uses video recordings and trajectory extraction software to create a microsimulation model of the traffic-calmed street. From the data, only dynamic behaviour of drivers was extracted, this included speed distributions, together with braking and acceleration when entering and leaving the reduced speed area. For further research, in order to improve the precision of the model, an attempt to estimate Wiedemann model parameters will be made. Moreover, the transfer of the simulation from a micro- to a macroscopic model must be made in order to estimate travel times in the situation, when the traffic flow is greater than capacity. Ultimately, a larger driving behaviour database and more types of traffic calming measures should be studied. This would be likely to deliver more precise forecasts of the impact of traffic calming than could be achieved using traditional methods. 


\section{References}

[1] A1 Braess D., On a Paradox of Traffic Planning, "Transportation Science”, 39, 2005, 446-450.

[2] Leeming J.J., Road Accidents: Prevent or Punish?, 1969.

[3] Downs A., Still Stuck in Traffic: Coping With Peak-Hour Traffic Congestion, 2004.

[4] J H Mogridge M., Travel in towns: jam yesterday, jam today and jam tomorrow?, 1990.

[5] Traffic Calming: State of the Practice ITE/FHWA, August 1999.

[6] https://www.gps.gov/systems/gps/performance/accuracy (access: 5.07.2018).

[7] Barbosa H.M., Impacts of traffic calming measures on speeds on urban roads, Diss. University of Leeds, 1995.

[8] http://datafromsky.com (access: 5.07.2018).

[9] A7 PTV-Ag, PTV VISSIM 9 User Manual, Karlsruhe 2017.

[10] Bliemer M.C.J. et al., Genetics of traffic assignment models for strategic transport planning, Transport Reviews 37.1, 2017, 56-78.

[11] Kucharski R., Drabicki A., Estimating Macroscopic Volume Delay Functions with the Traffic Density Derived from Measured Speeds and Flows, Journal of Advanced Transportation 2017. 